\title{
Nohut (Cicer arietinum L.)'un Verim ve Kalitesine Ahır Gübre Dozlarının Etkisi
}

\author{
Reyhan KARAYEL ${ }^{1 *}$, Arslan UZUN ${ }^{2}$, Hatice BOZOĞLU ${ }^{3}$ \\ Geliş / Received: 05/02/2020 \\ Revize / Revised: 06/03/2020 \\ Kabul / Accepted: 06/03/2020
}

\begin{abstract}
ÖZ
Kimyasalların bilinçsiz kullanımı doğal dengeyi bozmakta, çevre ve insan sağlığında ciddi tehditler yaratmaktadır. Doğal kaynakları kirletmeden verimi ve kaliteyi yükselterek să̆lıklı gıda elde etmek için organik gübrelerin kullanımı önerilmektedir. Bu öngörüler üzerine planlanan çalışmada, nohutun verim ve kalitesi üzerine ahır gübresinin etkisi araştırılmıştır. Bu amaçla 5 doz ahır $(0,750,1500,2250$ ve $3000 \mathrm{~kg} / \mathrm{da})$ ve bir doz kimyasal gübre $(4 \mathrm{~kg} / \mathrm{da} \mathrm{N})$ olmak üzere toplamda 6 doz gübre uygulaması yapılmıştır. Çalışma 2015 ve 2016 yıllarında farklı arazilerde yürütülmüş olup denemeler tesadüf blokları deneme desenine göre 3 tekrarlı olarak kurulmuştur. Materyal olarak "Sezenbey" nohut çeşidi kullanılmıştır. Yıllar üzerinden birleştirilerek yapılan varyans analizi sonuçlarına göre, biyolojik verim, bitkide bakla sayısı, tane verimi, tanedeki protein oranı, tanedeki $\mathrm{Fe}$ ve $\mathrm{Cu}$ içeriğinin gübre dozlarından istatistiki olarak etkilendiği tespit edilmiştir. Bakla sayısının 30.23-45.9 adet/bitki, tane veriminin 12.26-19.25 g/bitki, tanede ham protein oranının ise \% 18.90-21.56 arasında değiştiği belirlenmiştir. Protein oranı ve bitkide bakla sayısında tüm gübre uygulamalarının kontrolden farklı olduğu, tane veriminde ise kimyasal gübre uygulamasının en yüksek değeri verdiği tespit edilmiştir. Tane verimi ve tanedeki protein oranı, ahır gübresi dozları dikkate alınarak regrasyon analizine tabi tutulmuş ve gübre dozlarının tane verimine ikinci dereceden, protein oranının ise birinci dereceden önemli $(\mathrm{P}<0.05)$ etkisi olduğu belirlenmiştir.
\end{abstract}

Anahtar Kelimeler- Ahır gübresi, nohut, kalite ve verim özellikleri

\footnotetext{
1* Sorumlu yazar iletişim: reyhan.karayel@tarimorman.gov.tr (https://orcid.org/0000-0003-4312-6765)

Karadeniz Tarımsal Araştırma Enstitüsü Müdürlüğü, Samsun/Türkiye

2iletişim: arslan.uzun@hotmail.com (https://orcid.org/0000-0002-9895-0420)

Karadeniz Tarımsal Araştırma Enstitüsü Müdürlü̆̈̈̈, Samsun/Türkiye

3iletişim: hbozoglu@omu.edu.tr (https://orcid.org/0000-0003-4776-2566)

${ }^{3}$ Ondokuz Mayıs Üniversitesi Ziraat Fakültesi Tarla Bitkileri Bölümü, Samsun/Türkiye
} 


\title{
Effect of Farmyard Manure Doses on Yield and Quality of Chickpea (Cicer arietinum $\mathbf{L}$.)
}

\begin{abstract}
Unconscious use of chemicals disrupts the natural balance and creates serious threats to the environment and human health. It is recommended to use organic fertilizers to obtain healthy food by increasing yield and quality without polluting natural resources. In this study planned on these recommendations, effect of farmyard manure on the yield and quality of chickpea was investigated. For this purpose, total six doses fertilize treatments were carried out including five doses of farmyard manure $\left(0,750,1500,2250\right.$ and $\left.3000 \mathrm{~kg} \mathrm{da}^{-1}\right)$ and one dose of chemical fertilizer $\left(4 \mathrm{~kg} \mathrm{da}^{-1} \mathrm{~N}\right)$. The study was carried out in 2015 and 2016 in different lands and the trials have been established in randomized complete-block experimental design with three replications. Sezenbey chickpea variety was used in the trial. According to the results of variance analysis, which was combined over the years, it was determined that biological yield, number of pods in the plant, seed yield, protein content in the seed, Fe and $\mathrm{Cu}$ content in the seed were statistically affected by fertilizer doses. It is determined, the number of pods, seed yield the crude protein ratio in seed changed between 30.23-45.9 number plant ${ }^{-1}$, 12.26-19.25 g plant $^{-1}$, 18.9-21.6 $\%$ respectively. It was determined that all fertilizer applications are different from control in protein ratio and number of pods in the plant, whereas chemical fertilizer application gives the highest value in seed yield. Seed yield and protein ratio in the seed were subjected to regression analysis considering the farmyard manure doses, and It was determined that fertilizer doses were found to have significant $(\mathrm{P}<0.05)$ effect second degree on grain yield as first degree on protein ratio.
\end{abstract}

Keywords- Farmyard manure, chickpea, quality and yield characteristics 


\section{GIRIS}

Tarımda kültürel uygulamaların önemli ayaklarından biri olan kimyasal gübreleme üretimde artışlar sağlarken diğer yandan toprak, çevre ve sağlıklı ürün açısından birtakım olumsuzluklara neden olabilmektedir. Uygulama miktarı ve zamanı bu olumsuzlukların meydana gelmesinde önemli faktörler olarak görülmektedir. Tarım topraklarında gübrelemeden kaçınmanın söz konusu olamayacağı gerçeği dikkate alındığında, hatalı kullanımların azaltılması ve özellikle organik gübrelerle desteklenmesi gerekliliği ortaya çıkmaktadır [1].

Organik madde, toprak verimliliği ve sürdürülebilir tarım açısından son derece büyük bir öneme sahiptir. Ülkemiz tarım topraklarının tamamına yakınında organik madde içeriği yetersizdir. Topraklarımızdaki organik maddenin azlığı ve besin elementleri eksikliği, gerek çiftlik gübresinin gerekse diğer organik gübrelerin topraklara verilmesinin önemini ortaya koymaktadır [2].

Önemli bir organik madde kaynağı olan ahır gübresi, bir yandan toprak yapısının olumlu yönde etkilerken, diğer yandan bitkiler için besin elementi sağlayarak ürün miktarı üzerine olumlu etki yapar [3]. Ahır gübresinin en önemli özelliklerinden biri toprağın humus içeriğini arttırarak toprak yapısını iyileştirmektir. Organik maddenin 1:4 ile 1:3 kadarı kalıcı humus formundadır. Ahır gübresinin büyük bir kısmı toprakta uzun süre etkisini devam ettirmektedir. Ahır gübresinden, toprak mikroorganizmaları da yararlanır, mikroorganizmaların besin maddeleri ve özellikle enerji gereksinimlerinin önemli bir kaynağı humustur. Ahır gübresi bitki kökleri üzerine özellikle olumlu etkiye sahiptir, çünkü toprağın gevşemesi ve strüktürün gelişmesi aktivitesi ahır gübrelemesinin başlıca yararıdır [4]. Organik kökenli gübreler aynı zamanda bitkilerin istediği azotun kaynağıdır. Ancak toprakta bulunan azotun yaklaşık \% 40-50'si ilk yıl, \% 12-15'i ikinci yıl, \% 5-6'sı üçüncü yıl ve diğer yıllarda da kalan diğer kısmı yavaş yavaş ayrışarak, yarayışlı hale gelmekte ve bu nedenle kullanımı insan sağlığı açısından risk oluşturmamaktadır [5].

Nohut bitkisi, ülkemizin mutfak kültürünün ve son yıllar hariç tutulursa tarımsal ürün ihracatının en önemli ürünlerinden biridir. Bir baklagil bitkisi olan nohut kuraklığa dayanıklılığı, azot fiksasyon metabolizması ve köklerinin bol organik madde bırakması sayesinde münavebede yaygın olarak kullanılabilen, sürdürülebilirlik için yeri doldurulamaz nadir bitkilerden biridir [6]. Baklagil bitkilerinin azot fikse mekanizmalarının daha da iyi işleyebilmesi için organik madde çok önemlidir. Tahıllar gibi yüksek dozda azotlu gübrelemeye ihtiyaç duymayan, toprağı 1slah edebilme yeteneği olan nohudun verim ve kalitesine ahır gübresinin etkisini belirlemek için bu çalışma yürütülmüştür.

\section{MATERYAL VE YÖNTEM}

Bu çalışma "Sezenbey" nohut çeşidi kullanılarak 2014-2015 ve 2015-2016 yetiştirme sezonlarında Karadeniz Tarımsal Araş̧ırma Enstitüsü arazisinde yürütülmüştür.

Toprak analiz sonuçları incelendiğinde yıllar arasında sadece kireç bakımından farklılık olduğu; ilk arazinin çok az kireçli, ikincinin ise orta kireçli olduğu, geri kalan özelliklerinin benzer olduğu tespit edilmiştir (Tablo 1). Deneme arazilerinin toprak yapısının killi tınlı, hafif alkali, tuzsuz, fosfor içeriği çok yüksek, potasyum içeriği fazla, organik maddesi az olarak belirlenmiştir. Denemelerin yürütüldüğü dönemlere ait bazı iklim verileri Şekil 1 ve Şekil 2'de verilmiştir.

Tablo 1. Denemenin yerlerine ait toprak analiz sonuçları

\begin{tabular}{lllll}
\hline & \multicolumn{2}{c}{$\mathbf{2 0 1 5}$} & \multicolumn{2}{c}{ 2016 } \\
\cline { 2 - 5 } & Analiz Sonucu & Derecesi & Analiz Sonucu & Derecesi \\
\hline İşba & $\% 57$ & Killi tın & $\% 55$ & Killi tın \\
pH & 7.43 & Hafif alkali & 7.64 & Hafif alkali \\
Kireç $\left(\mathbf{C a C O}_{\mathbf{3}}\right)$ & $\% 1.0$ & Çok az kireçli & $\% 6.0$ & Orta kireçli \\
Total tuz & $\% 0.019$ & Tuzsuz & $\% 0.016$ & Tuzsuz \\
Fosfor $\left(\mathbf{P}_{\mathbf{2}} \mathbf{O}_{\mathbf{5}}\right)$ & $27.57 \mathrm{~kg} / \mathrm{da}$ & Çok yüksek & $18.87 \mathrm{~kg} / \mathrm{da}$ & Çok yüksek \\
Potasyum $\left(\mathbf{K}_{\mathbf{2}} \mathbf{O}\right)$ & $67 \mathrm{~kg} / \mathrm{da}$ & Fazla & $98 \mathrm{~kg} / \mathrm{da}$ & Fazla \\
Organik madde & $\% 1.91$ & $\mathrm{Az}$ & $\% 1.67$ & $\mathrm{Az}$ \\
\hline
\end{tabular}


Denemeler iki yılda farklı arazilerde, tesadüf blokları deneme desenine göre 3 tekrarlamalı olarak kurulmuştur. Çalışmada 5 doz yanmış ahır gübresi (6-7 yıl beklemiş) (0, 750, 1500, 2250 ve $3000 \mathrm{~kg} / \mathrm{da} \mathrm{kuru}$ ağırlık) ve bir doz kimyasal gübre $(4 \mathrm{~kg} / \mathrm{da} \mathrm{N})$ kullanılmıştır. Ahır gübresi ekimden 4 ay önce (birinci yıl 11.12.2014, ikinci yıl 10.12.2015) parsellere dağıtılıp karıştırılarak uygulanmıştır. Ahır gübresinin içeriği Tablo 2 'de verilmiştir. Kimyasal gübre uygulaması ise ekimle birlikte yapılmıştır. Ekimler her iki yılda da mart ayının ilk haftasında her parselde 4 sıra olacak şekilde 50x8 cm ekim sıklığında yapılmıştır.

Tablo 2. Denemede kullanılan ahır gübresinin analiz sonuçları

\begin{tabular}{|c|c|c|}
\hline Parametreler & 2015 & 2016 \\
\hline pH & 8.17 & 7.71 \\
\hline Organik madde, \% & 28.09 & 26.17 \\
\hline Organik C,\% & 14.04 & 13.09 \\
\hline Toplam N, \% & 0.94 & 1.00 \\
\hline $\mathbf{C} / \mathbf{N}$ & 14.94 & 13.09 \\
\hline Toplam P, \% & 0.27 & 0.53 \\
\hline Toplam K, \% & 0.39 & 0.51 \\
\hline Toplam Ca, \% & 2.33 & 2.88 \\
\hline Toplam Mg, \% & 0.58 & 0.57 \\
\hline Toplam Fe, mg kg-1 & 3393.22 & 3679.93 \\
\hline Toplam Zn, mg kg-1 & 86.81 & 126.39 \\
\hline Toplam Mn, mg kg & 357.39 & 444.03 \\
\hline
\end{tabular}

Nodül gözlemleri \% 50 çiçeklenme döneminde ilk y1l 02.05.2015, ikinci yıl 31.05.2016 tarihlerinde her parselden kökleri ile birlikte alınan 5 bitkide yapılmıştır. Bitki köklerindeki toprağı uzaklaştırmak için kökler suda bekletilerek yıkanmıştır. Bitkinin toprak üstü aksamı, nodüller ve kök kısmı birbirinden ayrılmış ve tartılmıștır. Daha sonra $70^{\circ} \mathrm{C}^{\prime} \mathrm{de}$ sabit ağırlı̆̆a gelene kadar kurutulan örneklerde kuru madde oranları hesaplanmıştır. Kuru hasat olgunluğunda her parselden seçilen 5 bitkide agronomik özellikler ölçülmüştür. Hasat işlemi her iki yılda da temmuz ayının son haftası (22.07.2015 ve 25.07.2016) yapılmıştır. Tohumlarda 100 tane ağırlığı, protein (Dumas yöntemiyle), nişasta [7], amiloz [8] ve kül oranları ile mineral madde (K, P, Ca, Fe, Cu, $\mathrm{Zn}, \mathrm{Mg}$ ) [9] miktarları belirlenmiştir.

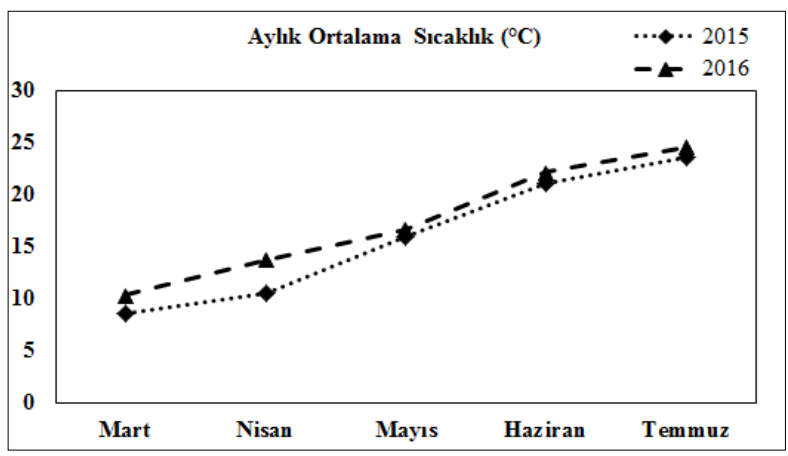

Şekil 1. Deneme dönemlerine ait aylık ortalama sıcaklık değerleri $\left({ }^{\circ} \mathrm{C}\right)$

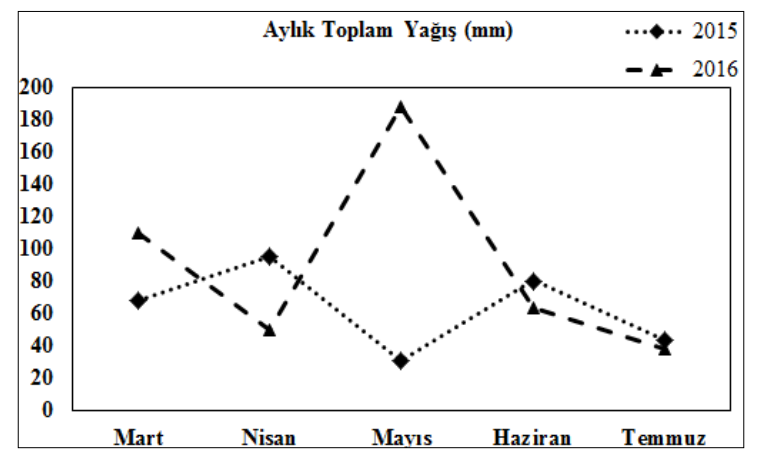

Şekil 2. Deneme dönemlerine ait aylık toplam yağış miktarı değerleri (mm)

İstatistik analizler homojenlik kontrolü yapıldıktan sonra yıllar üzerinden birleştirilerek tesadüf blokları deneme desenine göre SPSS-13 paket programı ile yapılmıştır. Çoklu karşılaştırma testleri $\mathrm{P}<0.05$ olasılıkla gübresiz uygulama dozu kontrol kabul edilerek DUNNET testine göre belirlenmiştir [10, 11]. Daha sonra kimyasal gübre uygulaması verilerden çıkarılıp, sadece ahır gübre dozlarına tekrar varyans analizi uygulanmış ve istatistiki önemlilik gösteren özelliklere regrasyon analizi yapılmıştır. 


\section{BULGULAR VE TARTIȘMA}

Baklagillerin azot fiksasyon kapasiteleri yetiştirildikleri toprak yapısına bağlı olarak değişmektedir. Toprak pH'sı, toprakta bulunan uygun bakteri 1rk1, toprak sıcaklığı, tuzluluğu, element içerikleri gibi birçok faktörün yanı sıra toprağın organik madde içeriğinin de azot fiksasyonuna etkisi vardır [10]. Değişkenlerin fazlalığı ve birbirleriyle interaksiyonları bunların etkilerinin ortaya çıkarılmasını zorlaştırmaktadır. Organik gübrenin sadece azot fiksasyonu ve bitkinin verim özelliklerine etkisinin yanı sıra toprağın canlılığının sürdürülebilirliği açısından da önemi vardır. Bu denemede organik gübrenin nohut bitkisinin gelişmesine etkisi araştırılmak istenmiştir. Çalışmada elde edilen veriler yıllar üzerinden birleştirilerek varyans analizi yapılmış ve incelenen tüm özelliklerin yıllardan istatistiki olarak etkilendiği tespit edilmiştir (Şekil 3). Özçelik ve Bozoğlu bitki boyu, bitkide bakla sayısı, bitkide tane sayısı, bin tane ağırlığı ve tane verimine ait basit kalıtım değerlerinin sirasıyla \% 58, 63, 62, 79 ve 49 olduğunu; bitki boyu, bakla sayısı ile tane veriminin pozitif ve önemli, bin tane ağırlığının ise negatif ve önemli olduğunu bildirmişlerdir [12]. Bu denemelerin yürütüldüğü yetiştirme dönemine ait sıcaklık ve yağış değerleri incelendiğinde ekim ayından hasada kadar olan süreçte ortalama sıcaklıklar her iki yılda da paralel gitmekle birlikte ikinci yıl değerlerinin ilk yıl değerlerinden birkaç derece daha fazla olduğu görülmüştür (Şekil 1). Toprak yapısının sadece kireç içeriğinde farklı olması nedeniyle, istatistik analizler sonucu yıllar arasında ortaya çıkan tüm özelliklerdeki farklılığın (Şekil 3) iklimsel ve özellikle de yağış faktöründen (Şekil 2) kaynaklandığı söylenebilir. Çiçeklenme dönemi ilk yıl mayısın ilk haftası iken ikinci yıl mayısın son haftası gerçekleşmiştir. Hasat dönemleri ise her iki yılda da temmuz ayının son haftasına denk gelmiştir ve ikinci yıl çiçeklenme periyodu kısa sürmüştür. İkinci yıl mayıs ayında düşen yağışlar vejetasyon süresini uzatıp bitki boyu, dal sayısı ve özellikle ilk bakla yüksekliğini artırdığı, bakla sayısının ise az olmasına sebep olmuştur. Dolayısıyla bitkide bakla sayısının az olmasına bağlı olarak bitkide tane veriminin düşük olduğu tespit edilmiştir (Şekil 3). Ayrıca verimi ve tüketimi etkileyen en önemli özelliklerden biri olan yüz tane ağırlığ ilk yıl 50.66 g, ikinci yıl 54.75 g olarak tespit edilmiştir. Nohutta 100 tane ağırlığını, Uzun ve ark. Amasya koşullarında 49.66 g, Altınbaş ve Sepetoğlu İzmir koşullarında 41.4 g, Erdin ve Kulaz Van-Gevaş koşullarında $38.04 \mathrm{~g}$, Yalçın ve ark. Yozgat koşullarında $41.3 \mathrm{~g}$ ve Afyonkarahisar koşullarında $41.2 \mathrm{~g}$ olarak tespit etmişlerdir $[13,14,15,23]$.

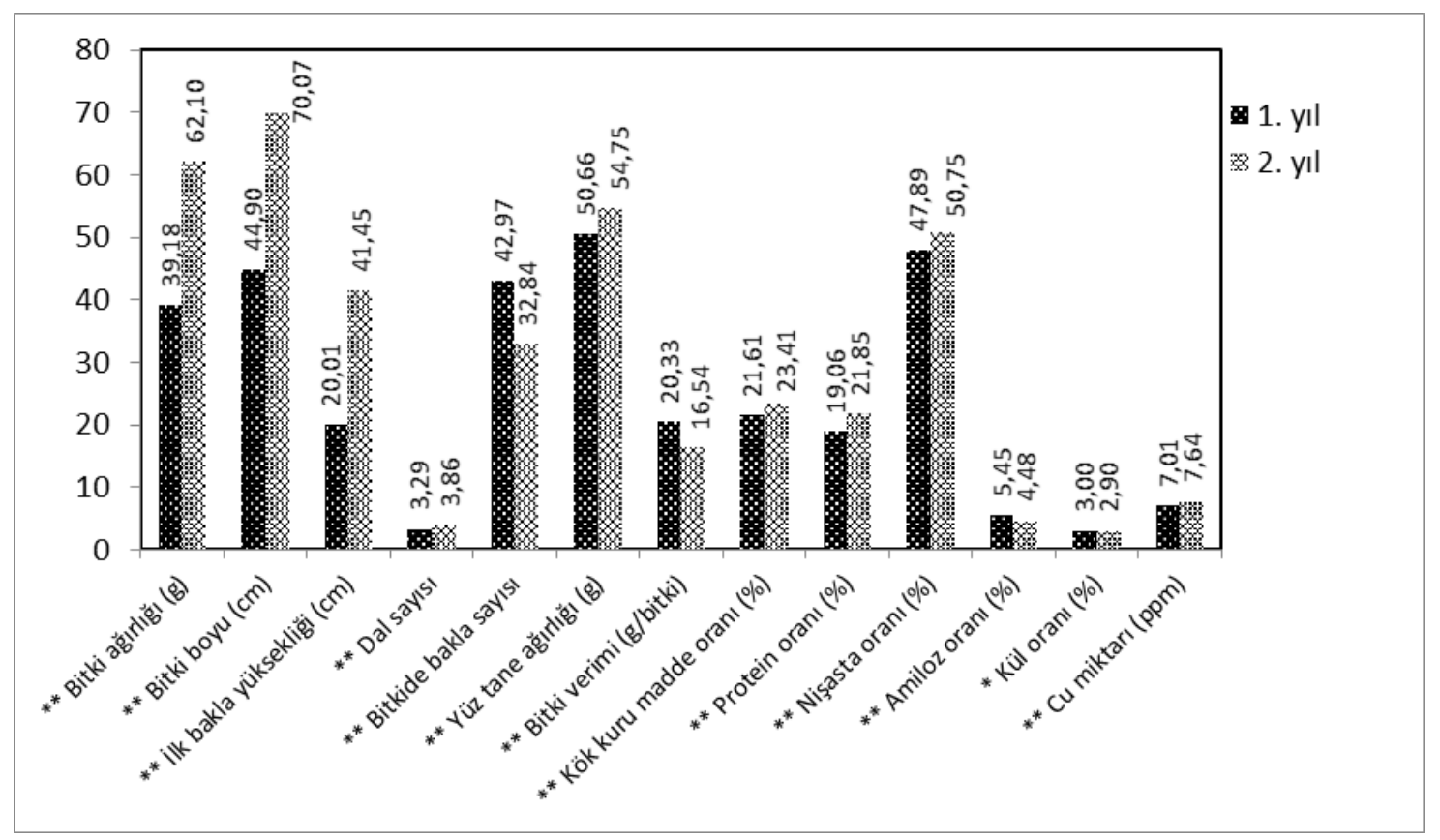

Şekil 3. Farklı ahır gübre dozları ile yetiştirilen nohut bitkisinin bazı özelliklerine ait yı1 ortalamaları 
Kimyasal ve organik gübrelerin bitkide bakla sayısı, tanede ham protein oranı, tanenin $\mathrm{Fe}$ ve $\mathrm{Cu}$ içeriğine; yıl x uygulama interaksiyonunun ise bitkide bakla sayısı, bitkide tane sayısı ve bitkide tane ağırlığına istatistiki olarak etki ettiği tespit edilmiştir (Tablo3).

Baklagillerde verimi etkileyen en önemli özelliklerinden biri bitkide bakla sayısıdır. Çalışmamızda nohutta bitkide bakla sayısının gübre uygulamalarında 30.23-45.90 adet arasında değişiklik gösterdiği tespit edilmiştir. En yüksek bakla sayısının dekara $4 \mathrm{~kg} \mathrm{~N}$ kimyasal gübresi uygulamasından elde edildiği belirlenmiştir. Bitkide bakla sayısı bakımından tüm gübre uygulamaları arasında istatistiki olarak $(\mathrm{P}<0.05)$ farklılık görüldüğü tespit edilmiştir. Ahır gübre dozlarında regrasyon analizi yapmak için kimyasal azot gübresi çıkarılarak varyans analizi yapıldığında gübre dozlarının bakla sayısına istatistiki etkisi olmadığı sonucuna varılmıştır. Bitkide bakla sayısını Uzun ve ark. Amasya koşullarında bazı nohut hatlarında 31.55 adet, Altınbaş ve Sepetoğlu İzmir koşullarında kışlık ekilen nohut hatlarında 27.9 adet olduğunu bildirmişlerdir [13, 14].

Demirbaş ve ark. farklı dozda azotlu gübreleme ve bakteri uygulamasının nohudun özelliklerine etkisini araştırdıkları saksı çalışmasında, en yüksek kök kuru madde miktarını hektara $120 \mathrm{~kg} \mathrm{~N}$ uygulanan ve bakteri inokulasyonu yapılan işlemden elde edildiğini, gübresiz ve bakteri uygulanmayan işlemler hariç nohudun kök kuru madde üretiminin N dozunun artışı ile arttığını belirlemişlerdir [16]. Çalışmamızda biyolojik verimi ifade edecek bitki ağırlığı gübre uygulamalarından istatistiki olarak etkilenirken kök ve gövde kuru madde miktarları arasında farklılık olmadığı sonucuna varılmıştır (Tablo3). Yapılan Dunnet testi sonucu gübresiz uygulama olan kontrol ile dekara $750 \mathrm{~kg}$ ahır gübresi verilen uygulama arasında istatistiki $(\mathrm{P}<0.05)$ fark olduğu tespit edilmiştir. Kontrolde 44.42 g olan bitki ağırlı̆̆ $750 \mathrm{~kg} /$ da ahır gübre dozunda 61.65 g'a çıkmış, doz artışına bağlı olarak da değerde bir azalış olmuştur. Bitkinin kök ve gövde kısımlarına ait kuru madde oranlarının birbirlerine yakın olduğu, kökte \% 21.98-23.11, gövdede ise \% 17.82-20.18 arasında değişkenlik gösterdiği belirlenmiştir. Değişen gübre uygulamalarında nodüllerin kuru madde oranları \% 17.98-19.75 arasında değiştiği ancak bu değişimin istatistiki olarak önemli olmadığı sonucuna varılmıştır.

Tablo3. Farklı ahır gübre dozları ile yetiştirilen nohut bitkisinin bazı özelliklerine ait ortalamaları.

\begin{tabular}{|c|c|c|c|c|c|c|}
\hline \multirow{2}{*}{ Özellikler } & \multicolumn{5}{|c|}{ Ahır Gübre Dozları (kg/da) } & \multirow[b]{2}{*}{$4 \mathrm{~kg} \mathrm{~N} / \mathrm{da}$} \\
\hline & $\mathbf{0}$ & 750 & 1500 & 2250 & 3000 & \\
\hline Bitki Boyu (cm) & 53.57 & 60.46 & 58.55 & 57.45 & 56.40 & 58.51 \\
\hline İlk Bakla Yüksekliği (cm) & 26.47 & 32.90 & 32.13 & 31.92 & 31.08 & 29.89 \\
\hline Dal Sayısı (adet) & 3.23 & 3.68 & 3.70 & 3.63 & 3.47 & 3.73 \\
\hline Bakla Sayısı (adet/bitki) & $35.05 \mathrm{a}$ & $44.40 \mathrm{a}$ & $35.13 \mathrm{a}$ & $36.73 \mathrm{a}$ & $30.23 \mathrm{~b}$ & $45.90 \mathrm{a}^{*}$ \\
\hline Biyolojik verim (g/bitki) & $44.42 \mathrm{~b}$ & $61.65 \mathrm{a}^{*}$ & $49.67 \mathrm{a}$ & $47.02 \mathrm{a}$ & $42.82 \mathrm{~b}$ & $58.27 \mathrm{a}$ \\
\hline Gövde kuru madde oranı (\%) & 20.18 & 17.99 & 17.82 & 18.39 & 19.18 & 18.08 \\
\hline Kök kuru madde oranı (\%) & 22.90 & 21.98 & 22.48 & 22.20 & 23.11 & 22.39 \\
\hline Nodül kuru madde oranı (\%) & 19.75 & 17.98 & 17.99 & 18.08 & 18.55 & 18.36 \\
\hline 100 tane ağırlığı $(g)$ & 54.34 & 51.75 & 53.08 & 52.32 & 51.32 & 53.40 \\
\hline Tane verimi (g/bitki) & $14.64 \mathrm{c}$ & $17.33 \mathrm{~b}$ & $14.57 \mathrm{c}$ & $17.21 \mathrm{~b}$ & $12.26 \mathrm{~d}$ & $19.25 \mathrm{a}^{* *}$ \\
\hline Tanede ham protein oranı (\%) & $18.90 \mathrm{~b}$ & $20.36 \mathrm{a}$ & $20.72 \mathrm{a}$ & $21.21 \mathrm{a}$ & $21.56 \mathrm{a}^{*}$ & $19.96 \mathrm{a}$ \\
\hline Nişasta oranı $(\%)$ & 49.10 & 50.23 & 49.26 & 48.50 & 49.09 & 49.75 \\
\hline Amiloz oranı (\%) & 5.00 & 4.94 & 4.90 & 4.92 & 4.92 & 5.09 \\
\hline Kül oranı (\%) & 2.97 & 2.96 & 2.94 & 2.93 & 3.00 & 2.88 \\
\hline Tanede K oranı (\%) & 0.981 & 0.994 & 0.973 & 0.986 & 1.041 & 0.963 \\
\hline Tanede P oranı (\%) & 0.2940 & 0.2953 & 0.2879 & 0.2974 & 0.2918 & 0.2842 \\
\hline Tanede Ca miktarı (ppm) & 888.78 & 942.19 & 890.37 & 924.31 & 850.54 & 926.78 \\
\hline Tanede Fe miktarı (ppm) & $45.91 \mathrm{a}$ & $42.97 \mathrm{a}$ & $46.34 \mathrm{a}^{*}$ & $43.64 \mathrm{a}$ & $46.03 \mathrm{a}$ & $41.40 \mathrm{~b}$ \\
\hline Tanede Cu miktarı (ppm) & $7.92 \mathrm{a}^{*}$ & $6.85 \mathrm{~b}$ & $7.35 \mathrm{a}$ & $7.52 \mathrm{a}$ & $7.52 \mathrm{a}$ & $6.78 \mathrm{~b}$ \\
\hline Tanede Zn miktarı (ppm) & 30.83 & 29.33 & 30.27 & 29.46 & 31.91 & 27.12 \\
\hline Tanede Mg oranı (\%) & 0.1324 & 0.1318 & 0.1330 & 0.1328 & 0.1380 & 0.1288 \\
\hline
\end{tabular}
$* * \mathrm{P}<0.001 ; * \mathrm{P}<0.005$

Çalışmada bitki başına tane verimi 12.26-19.25 g arasında değişmiştir. Kullanılan ekim normu dikkate alınarak hesaplama yapıldığında bu değer dekara $321-576 \mathrm{~kg}$ tane verimine denk gelecektir. En yüksek verim 4 $\mathrm{kg} / \mathrm{da} \mathrm{N}$ hesabıyla verilen kimyasal gübre uygulamasından elde edilmiştir. Bunu takip eden verim ise $750 \mathrm{~kg} / \mathrm{da}$ ahır gübresi uygulamasında olmuştur. Topalak ve Ceyhan Konya koşullarında farklı ekim zamanlarının nohutta 
tane verimine etkilerini araştırdıkları çalışmada Sezenbey çeşidinin tane verim ortalamasının $164.9 \mathrm{~kg} / \mathrm{da}$ olduğunu bildirmişlerdir [17]. Yalçın ve ark. Afyonkarahisar ve Yozgat'ta yaptıkları çalışmada sırasıyla ortalama tane verimini 116.4-211.6 kg/da ve 102.8-195.4 kg/da olarak belirlemişlerdir [23]. Yapılan varyans analizi sonucu ahır gübre dozlarının etkisinin istatistiki olarak önemli olduğu tespit edilen tane verimi için regrasyon analizi yapılmıştır. Analiz sonucu ikinci dereceden etkinin istatistiki olarak $(\mathrm{P}<0.05)$ önemli olduğu tespit edilmiştir (Şekil 4b). Bu veriden hareketle tane verimi için en ideal dozun $1062 \mathrm{~kg} / \mathrm{da}$ olarak tavsiye edilebileceği belirlenmiştir.

Elementer haldeki azot bitkiye verildiğinde bitki kökleri hemen besinden yararlanmakta ve verimde etkisi doğrudan ortaya çıkmaktadır. Ahır gübrelerinin kullanılmasında temel nedenlerden biri başta $\mathrm{N}$ olmak üzere bitkiye besin maddesi kazandırmak iken esas etkisi toprağ etme beklentisidir. Ancak bu zaman alacak bir süreçtir. Bu nedenle ahır gübresinden, uygulamanın yapıldığ ilk yıl kimyasal gübreler kadar hızlı sonuç vermesi beklenmemelidir. Çalışmada kimyasal gübre uygulaması çıkarılarak ahır gübre dozlarını içeren veriler tekrar varyans analizine tabi tutulduğunda artan ahır gübre dozlarının verime etkisi önemli bulunmamıştır.

Baklagiller familyasını, tarımı yapılan diğer bitkilerden ayıran en önemli özelliklerinden biri kuru tanelerindeki protein oranının yüksek olmasıdır. Proteinler, bütün yaşamsal aktivitelerde rol oynayan moleküllerdir. Biyolojik moleküller içinde en karmaşık yapıya sahip olan proteinler, bu özelliklerinden dolayı çok geniş bir görev yelpazesine sahiptirler [18]. Çalışmamızda tane ham protein oranının \% 18.90-21.56 arasında değiştiği belirlenmiştir. En yüksek protein oranı $3000 \mathrm{~kg} / \mathrm{da}$ ahır gübresi uygulamasından elde edilmiş olup diğer gübre uygulamaları ile aynı istatistiki grupta yer almıştır. Yapılan Dunnet testine göre kimyasal gübre dahil tüm ahır gübresi dozlarının gübre verilmeyen işlemden istatistiki $(\mathrm{P}<0.05)$ olarak farklılık gösterdiği tespit edilmiştir. $\mathrm{Bu}$ sonuç proteinin en önemli yapıtaşı olan $\mathrm{N}$ un kimyasal veya organik olarak verilmesinin proteinin oranını arttırdığını göstermektedir. Erdin ve Kulaz Van-Gevaş ekolojik koşullarında bazı nohut çeşitlerinin ikinci ürün olarak yetiştirilmesini araştırdıkları çalışmada tanedeki protein oranını \% 20.1 olarak tespit etmişlerdir [15]. Kahraman ve ark. nohut tanesinde bulunan önemli kalite unsurları arasındaki ilişkileri belirledikleri çalışmada protein oranı ile nitrojensiz öz maddeler arasında önemli negatif, kükürt miktarı arasında önemli pozitif ilişki bulmuşlardır. $\mathrm{Bu}$ nedenle protein oranının artırılması için nitrojensiz öz maddeler ve kükürt miktarı üzerinde durulması gerektiğini bildirmişlerdir [19]. Yapılan varyans analizi sonucu ahır gübre dozlarının etkisinin istatistiki olarak önemli olduğu tespit edilen tanede protein oranı için regrasyon analizi yapılmıştır (Şekil 4a). Analiz sonucu birinci dereceden (linear) etkinin istatistiki olarak $(\mathrm{P}<0.05)$ önemli olduğu tespit edilmiştir. $\mathrm{Bu}$ veriden hareketle baklagillerin en önemli özelliği olan protein içeriğine ahır gübre dozlarının artırılarak çalışılması gerektiği sonucu çıkarılabilir.

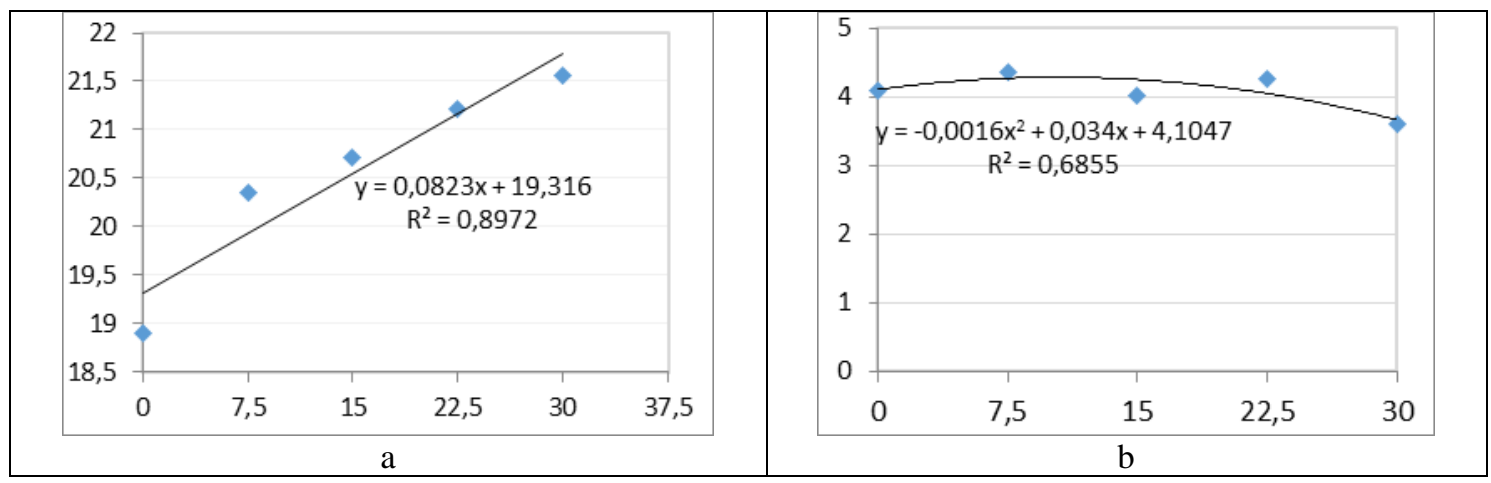

Şekil 4. Farklı ahır gübre dozları ile yetiştirilen nohut bitkisinin protein oranı (a) ve bitkide tane verimine (b) ait regrasyon grafikleri.

Baklagillerin tane kalite özelliklerinden bir diğeri de içerdikleri karbonhidratlardır. Çalışmamızda değişen gübre dozlarında tanenin nişasta oranının \% 48.5-50.23; amiloz oranının ise \% 4.9-5.09 arasında olduğu ancak her ikisi için de farklılıkların istatistiki olarak önemli olmadığı sonucuna varılmıştır. 
Mineral elementlerin tamamını içeren kül oranı \% 2.88-3.00 arasında değişirken, istatistiki fark olmamasına rağmen en düşük kül oranının kimyasal gübre uygulamasında olduğu dikkat çekicidir (Tablo3). Tanedeki yedi farklı (Fe, Cu, K, P, Ca, Zn, Mg) elemente ait değerlerin bulunduğu çalışmada demir (Fe) ve bakır $(\mathrm{Cu})$ 'da gübre uygulamalarının istatistiki olarak farklılık gösterdiği tespit edilmiştir. Gıdalarda Fe elementi eksikliği kansızlık, baş dönmesi, halsizlik, iştahsızlık, nefes darlığı, vücut ısısının korunmasında yetersizlik ve kavram bozuklukları görülür [20]. Yetişkinlerde günlük Fe ihtiyacı erkeklerde 12 mg, kadınlarda 18 mg'dır [21]. $\mathrm{Bu}$ nedenle tüketilen gıdaların demir içeriklerinin yüksek olması istenmektedir. Çalışmamızda nohut bitkisinin tanesindeki Fe miktarının 41.40-46.34 ppm arasında değiştiğii, en yüksek Fe miktarının 1500 kg/da ahır gübresi dozundan elde edildiği ve kontrole nazaran azotlu kimyasal gübre uygulamasının istatistiki olarak $(\mathrm{P}<0.05)$ farklı olduğu sonucuna varılmıştır. Dikkati çeken kimyasal gübrede Fe'in en az olmasıdır (Tablo3). Mut ve Gülümser Damla-89 nohut çeşidinin bazı kalite özellikleri üzerine etkilerini araştırdıkları çalışmada tanede Fe miktarını 1. yıl 29.52 ppm ve 2. yıl 29.94 ppm olarak tespit etmişlerdir [22]. Erbaş Köse ve Mut 25 nohut hat ve/çeşidi ile yürüttükleri çalışmada potasyum içeriğini 7314.3-9980.1 mg kg-1, fosfor içeriğinin 1969.9-3705.3 mg kg-1, kükürt içeriğinin 1417.2-2224.6 mg kg-1, kalsiyum içeriğinin 963.1-1908.4 mg kg-1, magnezyum içeriği 844.2$1267.2 \mathrm{mg} \mathrm{kg}-1$, sodyum içeriği 403.2-1027.2 mg kg-1, çinko içeriğinin 14.2- 23.8 mg kg-1, demir içeriğinin 37.5-79.1 mg kg-1, bor içeriğinin 7.1-12.9 mg kg-1, mangan içeriğinin 10.9-23.2 mg kg-1 ve bakır içeriğinin 5.58-8.22 mg kg-1 arasında değiştiğini bildirmişleridir [24]. Tablo3 incelendiğinde elementler içerisinde en yüksek rakamsal değerlerin Ca elementinden elde edildiği görülmektedir. Nitekim baklagiller önemli Ca kaynağı gidalarıdır.

Bakır, vücutta Fe'in kullanılması ve enzimlerin çalışmasında rol alır. Günlük Cu ihtiyacı 0.6-2.0 mg'dır [21]. Eksikliğinde de fazlalığında da bir takım problemler oluşmaktadır. Bu çalışmada tanedeki Cu miktarının 6.78-7.92 ppm arasında değiştiği tespit edilmiştir. En yüksek $\mathrm{Cu}$ içeriğinin kontrol parselinden elde edildiği, 750 $\mathrm{kg} / \mathrm{da}$ ahır gübresi ve $4 \mathrm{~kg} / \mathrm{da} \mathrm{N}$ dozu hariç geri kalan ahır gübre dozlarının kontrol ile aynı grupta yer aldığı görülmüştür. Gübre uygulamalarındaki bu dalgalanmayı açıklayabilmek için test edilen örnek sayısının çoğaltılması gereklidir. Mut ve Gülümser Damla-89 nohut çeşidinin bazı kalite özelliklerini araştırdıkları çalışmada tanede bakır içeriğini ilk yıl 10.00, ikinci yıl ise 11.68 ppm olarak belirlemişlerdir [22]. Görüldüğü gibi mineral elementlerle ilgili verilerde denemelerin kurulduğu parsellerde hem deneme başında hem deneme sonunda alınacak örneklerde ayrı ayrı toprak analizlerin yapılarak üründeki miktarlarının yorumlanması daha doğru olacaktır.

\section{SONUÇLAR}

Tarımda yapılan yanlış uygulamalarının sadece tarımsal üretimde değil çevrede de çok önemli problemler yarattığı düşünüldüğünde, geleneksel tarımın en önemli girdilerinden biri olan ahır gübrelerinin kullanımının önemi tekrar gündeme gelmektedir. Tarla bitkileri içerisinde gerek kök yapısı, gerekse simbiyotik yaşam oluşturma yetenekleri nedeniyle baklagiller toprağı 1slah edici bitkiler olarak bilinmektedir. Toprak ıslahı ve sürdürülebilirliği için bu iki değerin bir araya getirilerek incelenmesi amacıyla yürüttüğümüz bu çalışmada, her iki deneme yıllında toprak özelliklerinin benzer olmasından dolayı özellikle yağış faktörünün tüm özellikleri etkilediği söylenebilir. Bitkide bakla sayısı, bitki ağırlı̆̆ı, bitkide tane verimi, tanede protein oranı, $\mathrm{Fe}$ ve $\mathrm{Cu}$ içeriğine gübre uygulamalarının istatistiki etkisi olduğu belirlenmiştir. Azot fiksasyon yetenekleri nedeniyle baklagiller için önerilen kimyasal gübre dozu olan $4 \mathrm{~kg} / \mathrm{da} \mathrm{N}$ uygulamasının kontrole nazaran bitkide bakla sayısı ve tane verimini artırdığı sonucuna varılmıştır. Kalite özelliklerinden olan protein, demir ve bakır içeriğini ise ahır gübre uygulamasının artırdığı gözlenmiştir. Ancak yapılan regrasyon analizlerinde linear etkinin önemli olması dozların artırılarak çalışmaların sürdürülmesi gerektiğini göstermektedir. Kullanılan ahır gübresinin verimlilikten çok kalite özelliklerinde daha etkin oluşu bu çalışmanın başlatılmasının nedenlerinden biri olan toprak canlılığı ve buna bağlı olarak daha sağlıklı baklagil yetiştiriciliği ve çevre dostu tarım yapılabileceğini doğrulamaktadır. Ancak ahır gübreleri verildikten sonra içerisindeki azotun birkaç yılda yavaş yavaş kullanılıyor olması nedeniyle dozlarının toplam kuru maddedeki içeriğinden çok bu içeriğin ilk yıl ne kadarının kullanılması gerektiğinden hareketle hesaplanması, uzun yıllar süren denemelerde gübrenin uygulandığı alanın çakılı deneme halinde yürütülmesi ya da takip eden yıllardaki bitkilerde de gözlemlerin alınması, ahır gübresinin toprak ıslah edici özelliğinin de belirlenebilmesi için toprak ve özellikle mikroorganizma durumunun incelenmesi doğru olacaktır. 


\section{KAYNAKLAR}

[1] Sönmez, İ., Kaplan, M., \& Sönmez, S. (2008). Kimyasal gübrelerin çevre kirliliği üzerine etkileri ve çözüm önerileri. Batı Akdeniz Tarımsal Araştırma Enstitüsü Derim Dergisi, 25 (2), 24-34.

[2] Yetgin, M. A. (2010). Organik Gübreler ve Önemi. Samsun Tarım İl Müdürlüğü Yayını, 20.

[3] Karaman, M.R. (2012). Bitki Besleme (1. Bask1). Dumat Ofset, Matbaacılık San. Tic. Ltd. Şti., Ankara, 1067.

[4] Elinç, F. 2007. Gübreler ve Gübreleme. Ondokuz Mayıs Üniversitesi, Ziraat Fakültesi, Samsun, 327.

[5] Herbert, S. J. (1998). Farmyard manure crop dairy, livestock news. University of Massachusetts Amherst. USA, 311.

[6] Kahraman, A. (2017). Effect of humic acid applications on the yield components in chickpea. Gaziosmanpaşa Üniversitesi Ziraat Fakültesi Dergisi, 34 (1), 218-222.

[7] Anonim (1999). Determination of starch, polarimetric method, Official Journal of the European Communities, 1999/79/EC.L 209/25-27.

[8] Juliano, A.O. (1971). A simplified assay for milled rice amylose. Cereal. Science Today, 16, 334-340.

[9] Kacar, B. (1984). Bitki Besleme Uygulama Klavuzu. Ankara Üniversitesi Ziraat Fakültesi Yayınları, Ankara.

[10] Gülümser, A., Bozoğlu, H., \& Pekşen, E. (2013). Araştırma Deneme Metotları. OMÜ Ziraat Fakültesi Ders Kitab1 No:48, 3. Bask1, 264.

[11] Genç, S., \& Soysal, M.İ (2018). Parametrik ve parametrik olmayan çoklu karşılaştırma testleri. Black Sea Journal of Engineering and Science, 1 (1), 18-27.

[12] Özçelik, H., \& Bozoğlu, H. (2004). Nohut çeşitlerinin tane verimi ve bazı özellikleri arasındaki ilişkiler ve kalıtım derecelerinin belirlenmesi. OMÜ Ziraat Fakültesi Dergisi, 19 (3), 8-13.

[13] Uzun, A., Özçelik, H., \& Yılmaz S. (2012). Seçilmiş bazı nohut (Cicer arietinum L. ) hatlarının agronomik ve kalite özellikleri bakımından değerlendirilmesi. Akademik Ziraat Dergisi, 1 (1), 29-36.

[14] Altınbaş, M., \& Sepetoğlu, P. (2003). Kışlık ekilen nohut hatlarında verim ve bazı tarımsal özellikler için performans ve adaptasyon ilişkisi. Ege Üniversitesi Ziraat Fakültesi Dergisi, 40 (1), 49-56.

[15] Erdin, F., \& Kulaz, H. (2014). Van-Gevaş ekolojik koşulların da bazı nohut (Cicer arietinum L.) çeşitlerinin ikinci ürün olarak yetiştirilmesi. Türk Tarım ve Doğa Bilimleri Dergisi, 1, 910-914.

[16] Demirbas, A., Durukan, H., Karakoy, T., Pamiralan, H., Gok, M., \& Coskan, A. (2018). Yield and nutrient uptake improvement of chickpea (Cicer arietinum L.) by dressing fertilization and nitrogen doses. Sceindo, $1(1), 51-57$.

[17] Topalak, C., \& Ceyhan, E., (2015). Nohutta farklı ekim zamanlarının tane verimi ve bazı tarımsal özellikler üzerine etkileri. Selçuk Tarım Bilimleri Dergisi, 2 (2), 128-135.

[18] Kandemir, N., \& Kavaklı, İ.H. (2001). Proteinler ve Protein Mühendisliği. Editörler: Özcan, S., Gürel, E., Babaoğlu, M., Bitki Biyoteknolojisi Cilt:2, S. Ü. Vakfıakfı Yayınları, Konya, 364-400.

[19] Kahraman, A., Önder, M., Ceyhan, E., \& Ulukuş, F. (2016). Nohut genotiplerinde cluster analizi ve önemli kalite parametreleri arasındaki ilişkiler. Tarla Bitkileri Merkez Araştırma Enstitüsü Dergisi, 25 (1), 196200. 
[20] Saldamlı, İ., \& Sağlam, F. (1998). Vitaminler ve mineraller. Gıda Kimyası, Hacettepe Üniversitesi Yayınları, Ankara, 337-398.

[21] Demirci, M. (2003). Glda Kimyası (2. baskı). Rebel Yayıncılık, İstanbul.

[22] Mut, Z., \& Gülümser, A. (2005). Bakteri aşılaması ile birlikte çinko ve molibden uygulamasının Damla-89 nohut çeşidinin bazı kalite özellikleri üzerine etkileri. OMÜ Zir. Fak. Dergisi, 20 (2), 1-10.

[23] Yalçın, F., Mut, Z. \& Erbaş Köse, Ö. D. (2018). Afyonkarahisar ve Yozgat Koşullarında Yüksek Verim Sağlayacak Uygun Nohut (Cicer arietinum L.) Çeşitlerinin Belirlenmesi. Gaziosmanpaşa Üniversitesi Ziraat Fakültesi Dergisi, 35 (1), 46-59.

[24] Erbaş Köse, Ö. D \& Mut, Z. (2019). Türkiye'de yetiştirilen nohut çeşit ve hatlarının mineral madde içeriklerinin belirlenmesi. Derim, 36(1), 73-78. 